\title{
First molecular data on the validity of Myxobolus ichkeulensis (Cnidaria: Myxosporea) from Mugil cephalus (Mugilidae) in Turkish waters
}

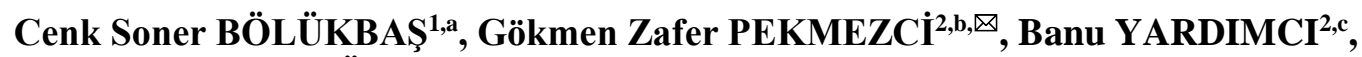 \\ Melek ÖZPIÇAK ${ }^{3, d}$, Savaş YILMAZ ${ }^{3, e}$, Nazmi POLAT ${ }^{3, f}$

\begin{abstract}
${ }^{1}$ Ondokuz Mayıs University, Faculty of Veterinary Medicine, Department of Parasitology, Samsun; ${ }^{2}$ Ondokuz Mayıs University, Faculty of Veterinary Medicine, Department of Aquatic Animal Diseases, Samsun; ${ }^{3}$ Ondokuz Mayis University, Faculty of Sciences and Arts, Department of Biology, Samsun, Turkey. ${ }^{\mathrm{a} O R C I D:}$ 0000-0002-4863-696X; ' $\mathrm{ORCID:}$ 0000-0002-7791-1959; ' ORCID:0000-0001-7232-554X; dORCID:0000-0003-3506-4242; ' ${ }^{\mathrm{e}}$ ORCID: 0000-0003-2859-4886; ' ORCID: 0000-0001-9785-9927
\end{abstract}

\author{
${ }^{凶}$ Corresponding author: zpekmezci@omu.edu.tr \\ Received date: 08.08.2019- Accepted date: 04.11.2019
}

\begin{abstract}
To date, there is no report on molecular characterisation of Myxobolus ichkeulensis in Mugil cephalus (Mugilidae) in Turkish marine waters. The aim of the current research was to provide the first molecular data on M. ichkeulensis from M. cephalus in Turkish Black Sea coasts. A total of 40 M. cephalus specimens were examined for the presence of M. ichkeulensis in the Turkish Black Sea coasts during January 2017 and April 2017. In the present study, M. ichkeulensis was identified based upon the myxospore morphology, host and tissue specificity, and SSU rRNA sequence. Phylogenetic analysis using neighbor-joining also revealed that our isolate (\#GZP-2018-Samsun1) was clustered with other Myxobolus species that infect M. cephalus. The current study includes the morphological and histopathological descriptions and first molecular data on M. ichkeulensis in M. cephalus in Turkish marine waters. M. ichkeulensis was also reported from the M. cephalus in the coast of the Black Sea in Turkey for the first time. Moreover, our current genetic data was recorded as the new valid SSU rRNA sequence (MH374629) for M. ichkeulensis in the GenBank database.
\end{abstract}

Keywords: Histopathology, morphology, Myxobolus ichkeulensis, SSU rRNA, Turkey

\section{Türkiye sularında Mugil cephalus'tan (Mugilidae) Myxobolus ichkeulensis'in (Cnidaria: Myxosporea) geçerliliğine ilişkin ilk moleküler veriler}

Özet: Bugüne kadar Türkiye karasularındaki Mugil cephalus (Mugilidae)'da Myxobolus ichkeulensis türünün moleküler karakterizasyonu ile ilgili kayıt yoktur. Bu araştırmanın amacı Türkiye'nin Karadeniz kıyılarında M. ichkeulensis türünün M. cephalus'lardaki varlığını hakkında ilk moleküler verileri sağlamaktır. Ocak 2017 ile Nisan 2017 tarihleri arasında Türkiye'nin Karadeniz kıyılarından $M$. ichkeulensis türünün varlığı için toplam 40 adet $M$. cephalus incelendi. Bu araştırmada M. ichkeulensis türü spor morfolojisi, konak ve doku spesifitesi ile SSU rRNA sekansına dayanarak teşhis edildi. İzolatımız (\#GZP-2018-Samsun1) neighbor-joining metodu kullanılan filogenetik analizde M. cephalus'ları enfekte eden diğer Myxobolus türleri ile kümelendi. Mevcut araştırma, Türkiye sularında $M$. cephalus'ta $M$. ichkeulensis türünün geçerliliği üzerine morfolojik ve histopatolojik tanımlamalar ile ve ilk moleküler verileri içermektedir. Türkiye'nin Karadeniz kıyılarından ilk kez M. cephalus'ta M. ichkeulensis türü de bildirildi. Ayrıca mevcut genetik verilerimiz GenBank veri tabanındaki M. ichkeulensis türü için yeni geçerli SSU rRNA dizisi (MH374629) olarak kaydedildi.

Anahtar sözcükler: Histopatoloji, morfoloji, Myxobolus ichkeulensis, SSU rRNA, Türkiye

\section{Introduction}

Thousands of myxosporean parasites are known to cause diseases in various marine and freshwater fish (18, 19). The genus Myxobolus Bütschli, 1882 is the largest group of Myxobolidae contains over 850 species described $(7,8)$. Based on spore morphology, host/ tissue tropism with the molecular marker are especially provided for identification of a new or existing myxozoa species and re-description of incompletely described species (11, 20). Myxobolus ichkeulensis was firstly described from the grey mullet Mugil cephalus in Ichkeul lagoon in Tunisia by Bahri and Marques (4). Later, there have been few reports on M. ichkeulensis in M. cephalus from Lake Ichkeul (Tunisia), Ebro River Delta (Spain), Baje de 
Gorée (Senegal), Black and Azov Seas (Crimea, Ukraine), Camlık Lagoon (north-eastern Mediterranean, Turkey) and Japan Sea (3, 9, 23, 24, 28, 31). Whereas, this Myxobolus species has been reported in different marine sources of the world, there were only two SSU rRNA sequences of $M$. ichkeulensis molecularly characterized and submitted to the GenBank with the accession numbers: AF378337 and AY129315 (3, 14).

Up to now, only four Myxobolus species have been morphologically identified and reported in M. cephalus from Turkish marine waters: M. episquamalis, M. exiguus, M. ichkeulensis and M. muelleri (2, 6, 23, 30). Whereas those species were morphologically described, there is no detailed molecular and histopathological data of $M$. ichkeulensis in $M$. cephalus in Turkish marine waters. The aim of the current research was to provide first molecular data on the validity of $M$. ichkeulensis from M. cephalus in Turkish marine waters.

\section{Material and Methods}

Sampling, morphological and histopathological examination: For this study, ethics committee approval was not needed because no handling of live fish specimens were involved. A total of forty freshly caught specimens of $M$. cephalus were periodically purchased from commercial fishermen at Kizilırmak Delta, Samsun coast located by the Black Sea, Turkey $\left(41^{\circ} 44^{\prime} 04.2^{\prime \prime N}\right.$ $\left.35^{\circ} 57^{\prime} 23.0^{\prime \prime} \mathrm{E}\right)$ in the period between January 2017 and April 2017. After purchase and transportation to the laboratory, $M$. cephalus were examined for $M$. ichkeulensis infections under a dissecting microscope (18). After whitish plasmodia were detected in the gills, plasmodia were isolated with a needle and opened on a slide. Infected gills containing mature plasmodia were fixed in $10 \%$ formaldehyde and embedded in paraffin. Paraffin blocks were cut into $5 \mu$ slices using microtome and stained with Hematoxylin-Eosin (H\&E). The position of the plasmodia in the gills was classified to Molnár (21). Some fresh spores were prepared in glycerine-jelly into the slide for morphological examination. Subsamples of fresh spores were preserved in absolute ethanol for molecular identifications. Myxospores were morphologically examined as previously reported Lom and Arthur (17) by measuring 20 freshly isolated mature spores in reference slide preparations. The myxospores were photographed and measured by Nomarski DIC optics connected to a digital camera. All measurements are presented in micrometres $(\mu \mathrm{m})$ with mean and range in parentheses.

DNA extractions and PCR analysis: Myxobolus spores were centrifuged at low speed, suspended in digestion solution and incubated at $56^{\circ} \mathrm{C}$ overnight. DNA was then extracted using a commercial DNA extraction kit
(GeneJET Genomic DNA Purification Kit, ThermoFisher Scientific) according to the procedure recommended by the manufacturer. Nested PCR assay was used for identification of Myxobolus species. The small subunit ribosomal RNA (SSU rRNA) gene ( 1900 bp) was amplified by first PCR using ERIB1 and ERIB10 primer pairs (5). Fifty $\mu$ l PCR reactions were contained 20-50 ng DNA, 2X Hot start PCR master mix, $0.4 \mu \mathrm{M}$ of each primer. Amplification of first PCR conditions were: $30 \mathrm{sec}$ at $95^{\circ} \mathrm{C}, 50 \mathrm{sec}$ at $43^{\circ} \mathrm{C}$, and $120 \mathrm{sec}$ at $72^{\circ} \mathrm{C}$ for $30 \mathrm{cycles}$, and a 10 min extension at $72{ }^{\circ} \mathrm{C}$. Then, second PCR were carried out in a final volume of $50 \mu \mathrm{l}$, which contained 1 $\mu \mathrm{l}$ of the first PCR amplicon, $2 \mathrm{X}$ hot start PCR master mix, $0.4 \mu \mathrm{M}$ of each primer. The $\sim 900 \mathrm{bp}$ amplification products using the MyxospecF-MyxospecR primer sets (12) were run with $30 \mathrm{sec}$ at $95^{\circ} \mathrm{C}, 50 \mathrm{sec}$ at $40{ }^{\circ} \mathrm{C}, 90 \mathrm{sec}$ at $72^{\circ} \mathrm{C}$ for 35 cycles, and products were subjected to a final extension at $72{ }^{\circ} \mathrm{C}$ for $10 \mathrm{~min}$. After amplification, PCR amplicons were electrophoresed on $1 \%$ agarose gel in a TBE buffer. Second PCR amplicons were sequenced both directions with MyxospecF-MyxospecR primer pairs by Sanger method (Macrogen, Netherlands).

Phylogenetic analyses: The obtained sequences were controlled by Vector NTI Advance 11.5 (Invitrogen, USA) using phred values. Then, sequences were de novo assembled and edited with using Contig Express (NTI Advance 11.5, Invitrogen, USA) and the created sequences were compared with GenBank accessions using the BLAST research (1). The SSU rRNA sequences were aligned with other known Myxobolus species from $M$. cephalus in previous studies $(3,14,15,28)$. Sequence aligments were performed with ClustalW in MEGA 7.0 (29) and adjusted manually. Phylogenetic tree was constructed using neighbor-joining (NJ) analysis in MEGA 7.0 (16). The Kimura two-parameter (K2P) model was used in the analysis. The species Ceratomyxa shasta was chosen as the out-group. The mugilid infecting Myxobolus sequence sets were built with 1000 bootstrap replications for the $\mathrm{NJ}$ reconstruction (10). Bootstrap values $\geq 70$ were considered well supported (13).

\section{Results}

Whitish cyst-like plasmodia were detected macroscopically along the conjunction line of the gill filaments and arches of $M$. cephalus. We concluded that our isolate (\#GZP-2018-Samsun1) is M. ichkeulensis based on the spore morphology, biological traits (host/organ specificity and tissue tropism) and molecular data.

Taxonomy of Myxobolus ichkeulensis (4)

Host: Grey mullet, Mugil cephalus (Mugilidae)

Locality: Kizilırmak Delta, Samsun, Turkey

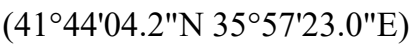




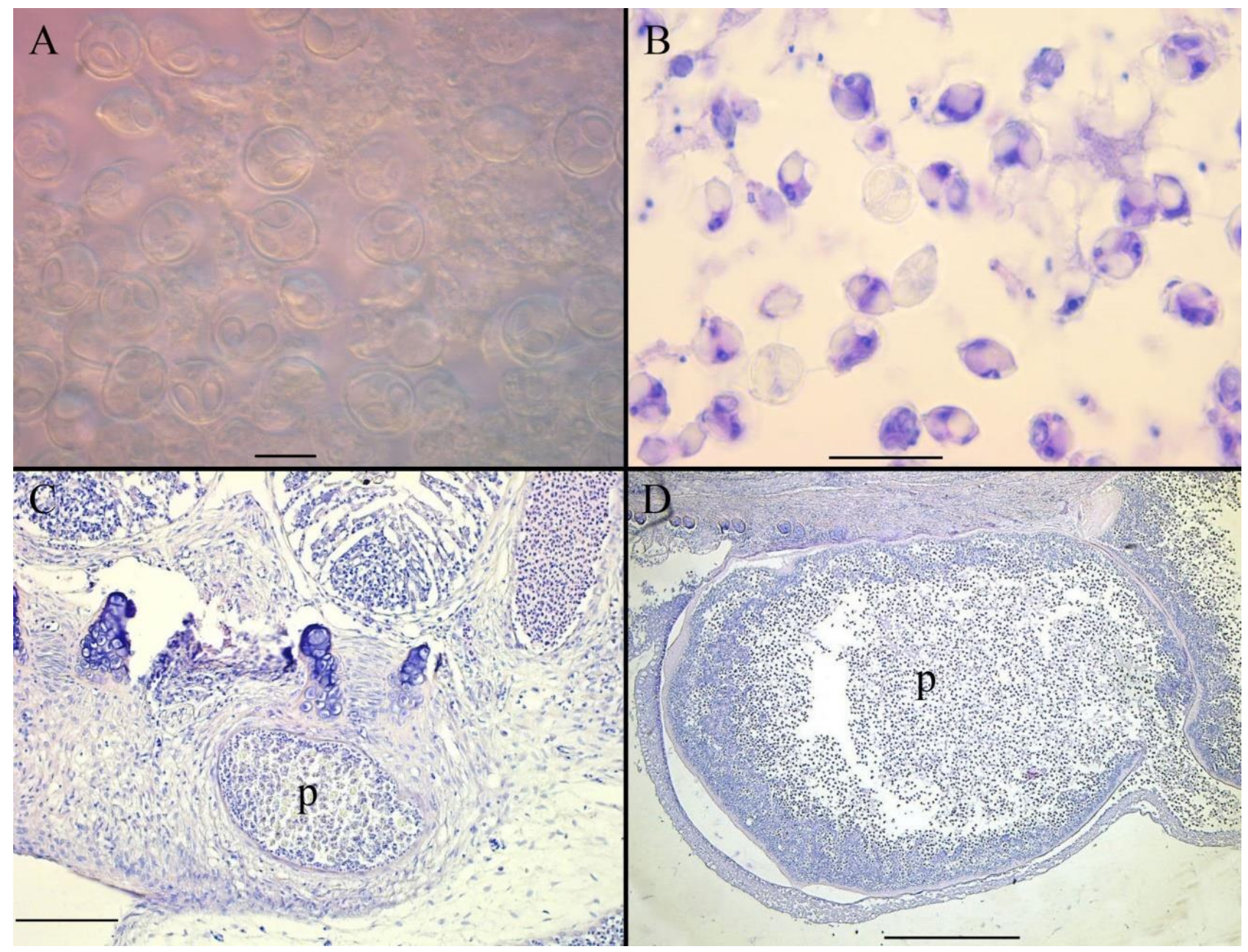

Figure 1. Microscopic photographs of M. ichkeulensis infecting the gill arch of M. cephalus.

A. Fresh myxospores of $M$. ichkeulensis in glycerine-jelly, scale: $10 \mu \mathrm{m}$. B. Myxospore of M. ichkeulensis inside plasmodium (p), histopathological section, H\&E staining, scale: $10 \mu \mathrm{m}$. C. M. ichkeulensis plasmodium (p) located in the connective tissue elements of the gill arch, histopathological section, H\&E staining, scale: $100 \mu \mathrm{m}$. D. A large plasmodium (p) of M. ichkeulensis in the gill arch, histopathological section, H\&E staining, scale: $500 \mu \mathrm{m}$.

Site of infection: Plasmodia were observed macroscopically as whitish cysts along the conjunction line of the gill filaments and arches.

Type material: Reference glycerine-jelly and histopathological sections were deposited in the laboratory. The SSU rRNA sequence of $M$. ichkeulensis was recorded in GenBank as MH374629.

Prevalence of infections: $12.5 \%$ (5 out of 40), 12 to 18-cm-sized fish

Myxospores: The myxospores were round or spherical. The spores were 13.3 (12.06 to 13.72) $\mu \mathrm{m}$ long $(\mathrm{n}=20), 11.42(10.5$ to 12.4$) \mu \mathrm{m}$ wide $(\mathrm{n}=20)$, and 8.24 ( 7.75 to 8.53$) \mu \mathrm{m}$ thick $(\mathrm{n}=10)$. The two polar capsules were oval, equal in size, 5.97 (5.7 to 6.65) $\mu \mathrm{m}$ long ( $\mathrm{n}=$ $20)$ and 3.81 (3.4 to 4.18$) \mu \mathrm{m}$ wide $(\mathrm{n}=20)$, and their posterior end reached half the length of the spore. Eight to ten sutural edge markings were easily observed (Figure 1A-B).
Histopathological findings: 250 to $2000 \mu \mathrm{m}$ in diameter plasmodia were found. The histopathological analysis revealed the development of the cyst-like plasmodia as gill arch type. Moreover, plasmodia were located in the connective tissue elements of the gill arch (Figure 1C-D).

Molecular data: No intraspecific nucleotide variability within three isolate of $M$. ichkeulensis from the Black Sea were observed in the SSU rRNA sequences. A BLAST search indicated that SSU rRNA sequence of our isolate GZP-2018-Samsun1 (MH374629) from $M$. cephalus showed $99.05 \%$ similarity to Myxobolus sp. voucher Spain6-tp (MF118764), which is also a tailinfecting species and identified as M. ichkeulensis, and shared $98.82 \%$ similarity with that of M. ichkeulensis (AF378337; AY129315). For this reason, our Myxobolus isolate (GZP-2018-Samsun1) thus identified molecularly to belong to M. ichkeulensis. 


\section{Discussion and Conclusion}

The flathead grey mullet M. cephalus (Mugilidae) is a cosmopolitan coastal fish species distributed worldwide. Several myxosporean parasites have been reported as serious pathogens of mugilid fish species $(22,31)$. Moreover, a great number of myxosporean species were recorded in M. cephalus among other mugiliform fish species. To date, thirty six species of myxosporeans have been reported and amongst them are M. muelleri, $M$. ichkeulensis, M. spinacurvatura, M. exiguus, M. parvus and $M$. episquamalis are only six cosmopolite species in M. cephalus from worldwide (31).

M. ichkeulensis was firstly described in M. cephalus by Bahri and Margues (4) based on traditional criteria, including tissue tropism and detailed light and electron microscopic examination of spore morphology and subsequently Bahri et al. (3) provided a supplemental data on M. ichkeulensis from the host type with molecular data of the SSU rDNA sequence (AY129315). Within the current study, the SSU rDNA sequences of our isolate
(\#GZP-2018-Samsun1) showed 98.82\% identity with reference sequence of M. ichkeulensis (AY129315). Therefore, we molecularly identified our Myxobolus species as M. ichkeulensis. Currently, based on spore morphology, host/organ specificity and tissue tropism with the molecular marker are mainly useful for new myxosporean species and re-description of insufficiently described species $(3,25-28,31)$. Thus, these approaches combined (morphology, biological traits, and molecular markers) were used for the validation of M. ichkeulensis in $M$. cephalus from Turkish waters for the first time. Moreover, this is also first report of M. ichkeulensis in M. cephalus from the coast of the Black Sea in Turkey. Furthermore, the phylogenetic tree showed that our isolate was clustered with $M$. ichkeulensis species previously known to be sequenced from M. cephalus (Figure 2). A comparison of M. ichkeulensis Bahri and Marques (4), spore morphometric data isolated from M. cephalus at different geographical areas is presented in Table 1.

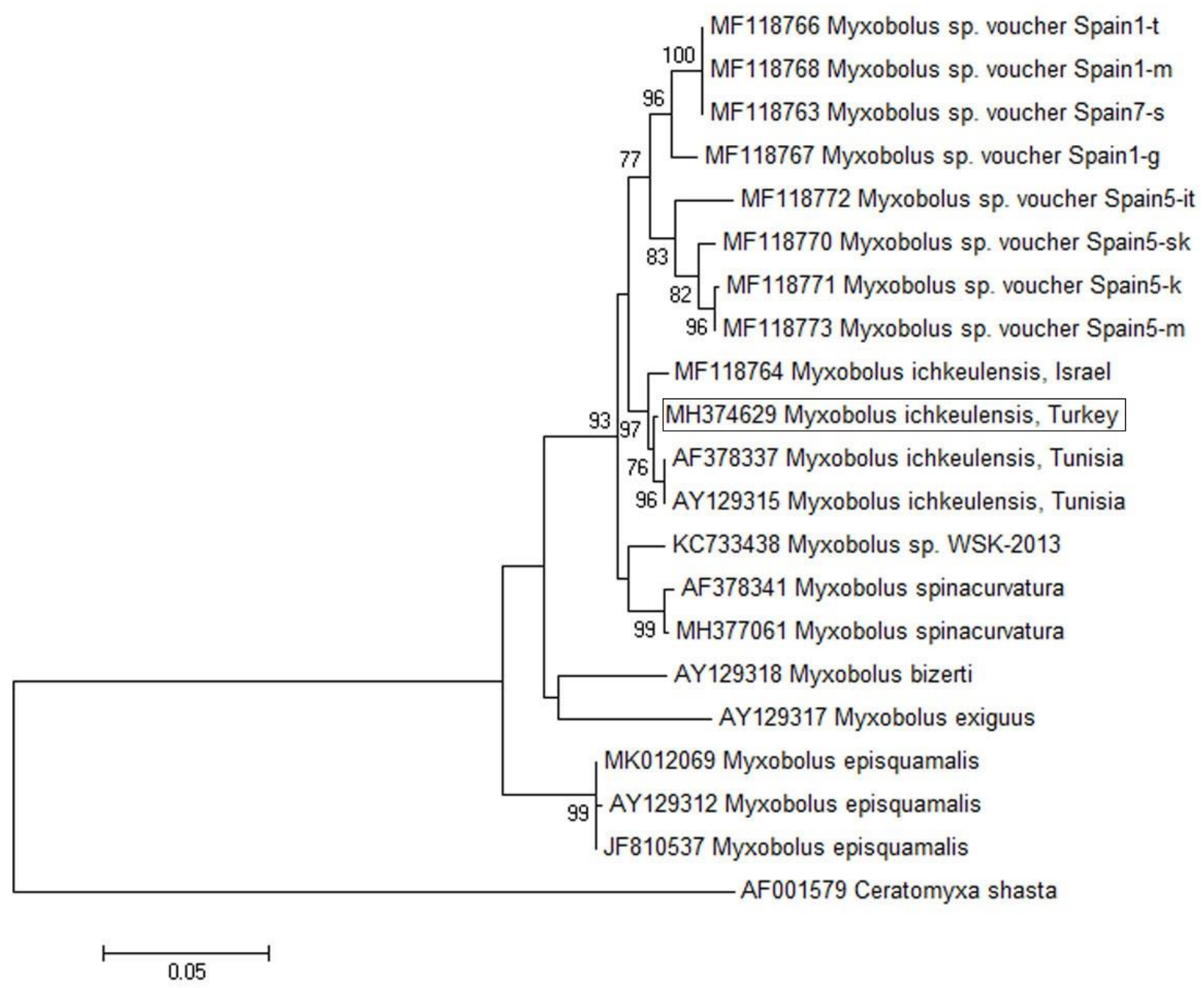

Figure 2. Phylogenetic tree generated by NJ analysis of the SSU rRNA sequences of M. ichkeulensis and other Myxobolus species infecting mugiliform.

Numbers at nodes indicate the bootstrap values. Ceratomyxa shasta was used as the out group. 
Table 1. Comparison of spore morphometric data $(\mu \mathrm{m})$ of M. ichkeulensis infection in M. cephalus.

\begin{tabular}{|c|c|c|c|c|c|c|}
\hline Spore length & Spore width & $\begin{array}{c}\text { Spore } \\
\text { thickness }\end{array}$ & $\begin{array}{c}\text { Polar capsule } \\
\text { length }\end{array}$ & $\begin{array}{c}\text { Polar capsule } \\
\text { width }\end{array}$ & Locality & Reference \\
\hline $\begin{array}{c}13.5 \\
(13-14)\end{array}$ & $\begin{array}{c}12.5 \\
(12-13)\end{array}$ & - & $\begin{array}{c}5.5 \\
(5-6)\end{array}$ & $\begin{array}{c}4.2 \\
(4-4.3)\end{array}$ & $\begin{array}{c}\text { Tunisia: } \\
\text { Ichkeul Lagoon }\end{array}$ & $\begin{array}{l}\text { Bahri and } \\
\text { Marques } \\
\text { (4) }\end{array}$ \\
\hline $13.5 \pm 0.54$ & $12.5 \pm 0.54$ & - & $5.5 \pm 0.54$ & $4.25 \pm 0.27$ & Tunisia: Ichkeul Lake & $\begin{array}{l}\text { Bahri et al. } \\
\text { (3) }\end{array}$ \\
\hline $\begin{array}{c}13.32 \\
(12.49-14.15)\end{array}$ & $\begin{array}{c}12.24 \\
(11.58-12.9)\end{array}$ & $\begin{array}{c}7.69 \\
(7.24-8.14)\end{array}$ & $\begin{array}{c}6.38 \\
(6-6.76)\end{array}$ & $\begin{array}{c}4.18 \\
(3.95-4.41)\end{array}$ & $\begin{array}{c}\text { Turkey: } \\
\text { Mediterranean coast, } \\
\text { Camlık Lagoon }\end{array}$ & $\begin{array}{l}\text { Ozak et al. } \\
\text { (23) }\end{array}$ \\
\hline $\begin{array}{c}13.13 \\
(12.06-13.72)\end{array}$ & $\begin{array}{c}11.42 \\
(10.5-12.4)\end{array}$ & $\begin{array}{c}8.24 \\
(7.75-8.53)\end{array}$ & $\begin{array}{c}5.97 \\
(5.7-6.65)\end{array}$ & $\begin{array}{c}3.81 \\
(3.4-4.18)\end{array}$ & $\begin{array}{c}\text { Turkey: } \\
\text { Black Sea coast, } \\
\text { Kızılırmak Delta }\end{array}$ & $\begin{array}{l}\text { Present } \\
\text { study }\end{array}$ \\
\hline
\end{tabular}

Myxosporean plasmodia localize in or among gill lamellae, in gill filaments and inside the gill arch cartilage (20). In the present study, histopathological sections showed M. ichkeulensis plasmodia in the connective tissue elements of the gill arch (Figure 1C-D). Myxosporean species is strictly connected to a specific tissue of the host (20). Myxosporean plasmodia may develop within the connective tissue layer in skin doublets between the fin rays $(20,21)$. Supportively, Myxobolus plasmodia embedding in the fin tail connective tissue was found in M. cephalus and was $99 \%$ similar to M. ichkeulensis (28). Our study and Sharon et al. (28) indicated that $M$. ichkeulensis in M. cephalus has an affinity for connective tissues both in the gill arch and tail fin. Moreover, small and single cysts of $M$. ichkeulensis reveal a basi-filamental type of plasmodial development in the M. cephalus (23).

In conclusion, supplementary data of histopathology and SSU rDNA analysis of M. ichkeulensis infecting $M$. cephalus as host type were provided in the present study for the first time from Turkish waters. Moreover, the new valid SSU rRNA sequence (MH374629) obtained from $M$. cephalus from Turkish waters has been submitted to the GenBank. This sequence can be also used to construct a phylogenetic tree with other mugiliform-infecting Myxobolus species.

\section{Acknowledgements}

A poster of this work was presented at the International Symposium on Ecology, Kastamonu, Turkey on June 20-23, 2018.

\section{Financial Support}

This research received no grant from any funding agency/sector.

\section{Conflict of Interest}

The authors declared that there is no conflict of interest.

\section{References}

1. Altschul S, Madden T, Schaffer A, et al (1997): Gapped BLAST and PSI-BLAST: a new generation of protein database search programs. Nucleic Acids Res, 258, 33893402.

2. Altunel FN (1983): Parasitism on mullets (Mugil spp.). J Fac Sci Ege Univ B, 1, 364-378.

3. Bahri S, Andree KB, Hedrick RP (2003): Morphological and phylogenetic studies of marine Myxobolus spp. from mullet in Ichkeul Lake, Tunisia. J Eukaryot Microbiol, 50, 463-470.

4. Bahri S, Marques A (1996): Myxosporean parasites of the genus Myxobolus from Mugil cephalus in Ichkeul lagoon, Tunisia: description of two new species. Dis Aquat Organ, 27, 115-122.

5. Barta JR, Martin DS, Liberator PA, et al (1997): Phylogenetic relationships among eight Eimeria species infecting domestic fowl inferred using complete small subunit ribosomal DNA sequences. J Parasitol, 83, 262-271.

6. Demirkale I, Cengizler I (2016): Identification of the infested gray mullets (Mugil cephalus L. 1758) by Myxobolus ichkeulensis level in the coast of Adana. TURJAF, 4, 805-812.

7. Eiras JC, Molnár K, Lu YS (2005): Synopsis of the genus Myxobolus Bütschli, 1882 (Myxozoa: Myxosporea: Myxobolidae). Syst Parasitol, 61, 1-46.

8. Eiras JC, Zhang J, Molnár K (2014). Synopsis of the species of Myxobolus Bütschli, 1882 (Myxozoa: Myxosporea, Myxobolidae) described between 2005 and 2013. Syst Parasitol, 88, 11-36.

9. Fall M, Kpatcha KP, Diebakate C, et al (1997): Observations sur des Myxosporidies (Myxozoa) du genre Myxobolus parasites de Mugil cephalus (Poisson, Téléostéen) du Sénégal. Parasite, 2, 173-180.

10. Felsenstein J (1985): Confidence intervals on phylogenies: an approach using the bootstrap. Evolution, 39, 783-791.

11. Fiala I, Bartošová-Sojková $\mathbf{P}$, Okamura B, et al (2015): Adaptive Radiation and Evolution within the Myxozoa. 6984. In: B Okamura, Gruhl A, Bartholomew JL (Eds), Myxozoan Evolution, Ecology and Development. Springer International Publishing, Switzerland.

12. Fiala I (2006): The phylogeny of Myxosporea (Myxozoa) based on small subunit ribosomal RNA gene analysis. Int $\mathrm{J}$ Parasitol, 36, 1521-1534. 
13. Hillis DM, Bull JJ (1993): An empirical test of bootstrapping as a method for assessing confidence in phylogenetic analysis. Syst Biol, 42, 182-192.

14. Kent ML, Andree KB, Bartholomew JL, et al (2001): Recent advances in our knowledge of the Myxozoa. J Eukaryotic Microbiol, 48, 395-413.

15. Kim WS, Kim JH, Oh MJ (2013): Morphologic and genetic evidence for mixed infection with two Myxobolus species (Myxozoa: Myxobolidae) in gray mullets, Mugil cephalus, from Korean waters. Korean J Parasitol, 51, 369373.

16. Kumar S, Stecher G, Tamura K (2016): MEGA7: molecular evolutionary genetics analysis version 7.0 for bigger datasets. Mol Biol Evol, 33, 1870-1874.

17. Lom J, Arthur JR (1989): A guideline for the preparation of species description in Myxosporea. J Fish Dis, 12, 151156.

18. Lom J, Dyková I (1992): Protozoan Parasites of Fishes. Elsevier, Amsterdam.

19. Lom J, Dyková I (2006): Myxozoan genera: definition and note on taxonomy, life-cycle terminology and pathogenic species. Folia Parasitol, 53, 1-36.

20. Molnár K, Eszterbauer E (2015): Specificity of Infection Sites in Vertebrate Hosts. 295-313. In: B Okamura, Gruhl A, Bartholomew JL (Eds), Myxozoan Evolution, Ecology and Development. Springer International Publishing, Switzerland.

21. Molnár K (2002): Site preference of myxosporeans in the gill. Dis Aquat Organ, 48, 197-207.

22. Ovcharenko M (2015): Microparasites of worldwide mullets. Ann Parasitol, 61, 229-239.

23. Ozak AA, Demirkale I, Cengizler I (2012): Two new records of Myxobolus Bütschli, 1882 (Myxozoa, Myxosporea, Myxobolidae) species from Turkey. Turk J Zool, 36, 191-199.
24. Pedro-Andrěs MB, Marques A, Gracia-Royo MP (2011): Myxosporean infection of grey mullet in the Ebro Delta: identification and ultrastructure of Myxobolus ichkeulensis Bahri \& Marques, 1996 infecting the gills of Mugil cephalus L. Acta Protozool, 50, 67-71.

25. Pekmezci GZ, Yardimci B, Yilmaz S, et al (2014): Myxobolus anatolicus sp. nov. (Myxozoa) infecting the gill of Anatolian khramulya Capoeta tinca (Cyprinidae) in Turkey. Dis Aquat Organ, 109, 213-222.

26. Pekmezci GZ, Yardimci B, Yilmaz S (2015): Supplementary studies and the first molecular data on Myxobolus scardinii Reuss, 1906 (Myxozoa: Myxosporea) infecting the gill filaments of rudd, Scardinius erythrophthalmus (L.). Parasitol Res, 114, 3619-3625.

27. Rocha S, Azevedo C, Oliveira E, et al (2019): Phylogeny and comprehensive revision of mugiliform-infecting myxobolids (Myxozoa, Myxobolidae), with the morphological and molecular redescription of the cryptic species Myxobolus exiguus. Parasitology, 146, 479-496.

28. Sharon G, Ucko M, Tamir B, et al (2019): Co-existence of Myxobolus spp. (Myxozoa) in gray mullet (Mugil cephalus) juveniles from the Mediterranean Sea. Parasitol Res, 118, 159-167.

29. Thompson JD, Higgins DG, Gibson TJ (1994): CLUSTALW: improving the sensitivity of progressive multiple sequence alignment through sequence weighting, position-specific gap penalties and weight matrix choice. Nucleic Acids Res, 2, 4673-4680.

30. Umur S, Pekmezci GZ, Beyhan YE, et al (2010): First record of Myxobolus muelleri (Myxosporea: Myxobolidae) in flathead grey mullet Mugil cephalus (Teleostei, Mugilidae) from Turkey. Ankara Univ Vet Fak Derg, 57, 205-207.

31. Yurakhno VM, Ovcharenko MO (2014): Study of Myxosporea (Myxozoa), infecting worldwide mullets with description of a new species. Parasitol Res, 113, 3661-3674. 